AL IBTIDA: JURNAL PENDIDIKAN GURU MI (2018) Vol 5 (1) : 107-132

DOI: http://dx.doi.org/ 10.24235/al.ibtida.snj.v5i1.2729

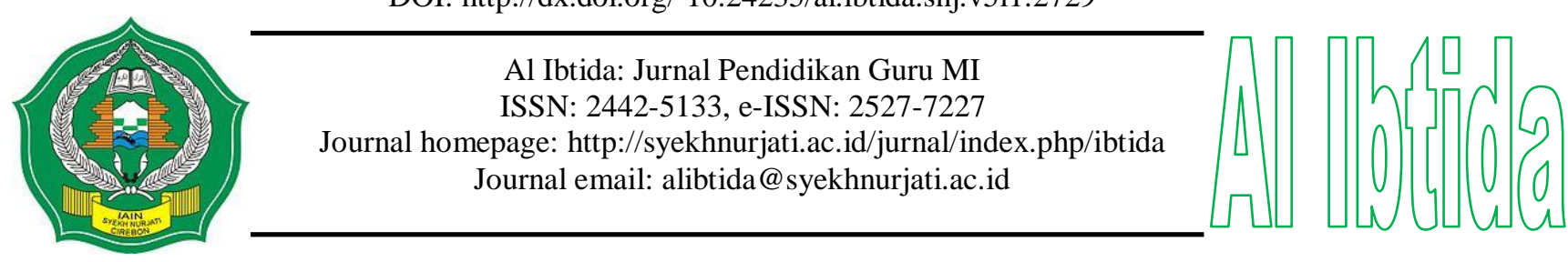

\title{
Nilai dan Keyakinan, Kreatifitas, dan Kepemimpinan Kepala Madrasah dalam Mengelola Madrasah Ibtidaiyah Negeri Malang 1 Kota Malang
}

\author{
Muhammad Walid* \\ *Program Studi Pendidikan Guru Madrasah Ibtidaiyah, Fakultas Ilmu Tarbiyah dan Keguruan, \\ UIN Maulana Malik Ibrahim Malang \\ Email:walidpgmi@gmail.com
}

Received 29 May 2018; Received in revised form: 08 June 2018; Accepted 11 June 2018

Publish Online: 29 June 2018

\begin{abstract}
Abstrak
Penelitian ini bermula dari pertanyaan mengapa ada madrasah yang berkualitas, namun ada juga yang tidak berkualitas. Pertanyaan berikutnya adalah mengapa madrasahmadrasah tersebut menjadi berkualitas sementara madrasah yang lain tidak berkualitas, apalagi menjadi unggulan, padahal sudah terdapat persamaan kesempatan antara madrasah dan sekolah untuk berkembang. Fokus penelitian ini adalah apa saja nilai-nilai dan keyakinan yang mendasari kepala madrasah dalam meningkatkan kualitas di MIN Malang 1 sehingga menjadi sukses dan bagaimana nilai-nilai dan keyakinan tersebut mewujud dalam kepemimpinan. Penelitian ini bertujuan untuk memperoleh pemahaman secara mendalam, oleh karenanya didekati dengan kualitatif dengan jenis studi kasus. Dalam pengumpulan data peneliti menggunakan tiga teknik, yaitu observasi partisipan (participant observation), wawancara mendalam (indepth interview), dan studi dokumen. Analisis data dilakukan dengan cara menguji, mengkategorikan, mentabulasi, atau pengkombinasian bukti-bukti empiris. Hasil penelitian menunjukan bahwa nilai-nilai dan keyakinan-keyakinan yang melandasi kepala sekolah/madrasah dalam mengelola perubahan di MIN Malang 1 diklasifikasikan menjadi nilai-nilai dan keyakinan religius, profesional dan kemanusiaan. Hal ini memberikan penjelasan bahwa keberhasilan MIN Malang 1 mencerminkan nilai-nilai dan keyakinan spiritual, profesional dan kemanusiaan yang dimiliki kepala madrasah mengenai hal-hal yang menjadi tujuan madrasah. Nilai dan keyakinan tersebut sangat berpengaruh terhadap praktik kepemimpinan kepala MIN Malang 1 dalam mengembangkan dan mengubah madrasah menjadi lebih baik.
\end{abstract}

Kata kunci: nilai dan keyakinan, kreatifitas, kepemimpinan, madrasah ibtidaiyah

\begin{abstract}
This research starts from the question why there is a madrasah quality, but some are not qualified.The next question is why these madrasah become qualified while other madrasah are not qualified and not excellent. Though there are similarities and opportunities between madrasah and schools to grow. The focus of this research is the values and beliefs that became the basis of madrasah leaders in improving quality in MIN Malang 1 thus that it becomes successful and how the values and beliefs come into being in leadership. This research aims to gain a deep understanding. Therefore researchers use a qualitative approach with case study. In data collecting researcher use three technique
\end{abstract}


are participant observation, in depth interview, and document study. Data analysis is done by testing, categorizing, tabulating, or combining empirical evidence. The results showed that the values and beliefs that became the foundation of the principal in managing change in MIN Malang 1 were classified into religious values and beliefs, professional and humanitarian. This explains the principal of madrasah has the values and beliefs of spiritual, professional and humanity which brings the success of MIN Malang 1. The values and beliefs are very influential on the principal's leadership practices in developing and changing the madrasah for the better.

Keywords: value and belief, creativity, leadership, and islamic elementary school

\section{PENDAHULUAN}

Sebagai lembaga pendidikan Islam, madrasah telah muncul dan berkembang sejalan dengan masuk dan berkembangnya Islam di Indonesia. Madrasah telah mengalami perkembangan jenis dan jenjangnya seiring dengan perkembangan bangsa Indonesia semenjak masa kesultanan, penjajahan dan kemerdekaan. Perkembangan tersebut telah mengubah pendidikan dari bentuk pengajian di rumah-rumah, terus ke musholla, masjid dan kebangunan sekolah seperti bentuk madrasah yang saat ini kita kenal. Dari sisi materi pendidikan, juga telah terjadi perkembangan dari yang tadinya hanya belajar mengaji al-qur'an, pelajaran ibadah praktis, terus ke pengajian kitab, lalu ke pengajaran agama di madrasah berupa mata pelajaran tauhid/akidah, akhlak, fiqh, hadis, tafsir, bahasa Arab dan sejarah Islam.

Namun, seiring dengan perkembanganya madrasah saat ini mengalami banyak masalah diantaranya persoalan mutu pendidikan dan manajerial. Sebagian besar madrasah dikelola oleh pihak swasta yang sering kali kurang mengedepankan asas-asas manajemen serta kualitas dan lebih mengutamakan pendekatan sosial sehingga susah berubah dan susah maju, walaupun sudah ada undang-undang yang mengatur kesetaraan madrasah dan sekolah umum. Keberadaan madrasah yang kebanyakan swasta dan berada di pelosok-pelosok desa juga menjadikan lembaga pendidikan Islam ini sulit berubah dan bersaing dengan sekolah-sekolah umum yang umumnya berstatus negeri dan disokong penuh oleh pemerintah. Sebagaimana data statistik menunjukkan bahwa 91\% madrasah berstatus swasta, dan hanya 8\% berstatus negeri (Emis Pendis 2017, Kompas.com, 04/10/2012). Hal inilah yang juga menjadikan perhatian pemerintah terhadap perkembangan madrasah sangat rendah, padahal jumlah madrasah jauh lebih banyak dari pada sekolah umum.

Meskipun sekarang ini perhatian pemerintah terhadap pendidikan Islam mulai bertambah, mulai dari pemberian sumbangan dana, kesempatan bekerjasama dengan pihak lain, penegerian swasta, kesempatan menjadi pegawai negeri bagi guru madrasah, namun keberadaan sisi manajerial yang sangat lemah menjadikan kebanyakan madrasah tahan hidup namun susah mati. Hidup mereka memang ditopang oleh masyarakat, sehingga tahan hidup dan susah mati. Namun 
masyarakat yang menopang madrasah adalah masyarakat yang rendah kemampuannya untuk mengelola lembaga pendidikan. Hal tersebut menyebabkan sangat jarang sekali ditemukan madrasah yang berkualitas.

Namun pada saat ini, kesetaraan madrasah dengan sekolah umum sudah mulai diupayakan. Hal ini secara otomatis menempatkan madrasah tidak lagi sebagai sekolah nomor dua di negeri ini setelah sekolah-sekolah umum. Saat ini pendidikan di madrasah dapat bersaing dengan pendidikan pada sekolah umum dan hal ini sejalan dengan pemberlakuan UndangUndang No 20 Tahun 2003 tentang Sistem Pendidikan Nasional (UU Sisdiknas)". Sebelum adanya UU tersebut, madrasah memang belum mendapatkan pelayanan yang seimbang dengan sekolah umum karena anggaran yang disiapkan di Depag (sekarang kemenag) masih menggunakan alokasi dana dari sektor agama. Setelah diberlakukannya UU itu, anggaran untuk pendidikan agama secara proporsional sama dengan anggaran untuk pendidikan di sekolah umum. Saat ini, unit cost (madrasah) tidak ada bedanya dengan unit cost sekolah (umum). Bahkan tidak ada lagi dikotomi antara sekolah umum dan sekolah agama (madrasah). Bila dikelola dengan benar, madrasah juga bisa menelorkan lulusan yang berkualitas. Madrasah bisa jadi sekolah unggulan.

Peluang madrasah untuk menjadi berkualitas dan memiliki kedudukan yang tidak berbeda dengan sekolah umum sangat terbuka lebar, sehingga asumsi masyarakat yang semula menilai madrasah pada umumnya "kelas dua" akan berubah dengan pikiran positif bahwa madrasah menerapkan sistem pendidikan yang terintegrasi antara pengajaran agama dan umum. Munculnya madrasah unggulan yang cukup banyak, sedangkan banyak pula sekolah umum (SD) yang ditutup menunjukan bahwa madrasah telah mampu berkompetisi dengan sekolah-sekolah umum. Di sisi lain, fenomena perkembangan dari penyimpangan prilaku siswa-siswi menjadi indikasi bahwa madrasah menjadi salah satu tumpuan harapan orang tua dalam pembinaan mental-spritual anaknya. Dengan demikian, madrasah adalah penjaga unsur religio-kultural anak didik (Dubin, 1991).

Integrasi madrasah dalam sistem pendidikan nasional menjadikan madrasah mengalami perubahan dan perkembangan yang sangat penting. Perubahan tersebut berujung pada satu tujuan, yakni peningkatan kualitas madrasah, baik sisi manajerial, kelembagaan, bahkan kurikulumnya. Perubahan dan perkembangan madrasah menjadikan madrasah dapat berdiri sejajar dengan sekolah-sekolah umum, sehingga banyak madrasah berkualitas unggul bermunculan, baik dalam bentuknya sebagai madrasah negeri maupun swasta. Hal ini dibuktikan dengan adanya temuan Steenbrink. Steenbrink mengindikasikan munculnya madrasah Ibtidaiyyah (MI) yang bermutu tinggi di beberapa kota besar di Indonesia. Bahkan madrasahmadrasah tersebut mampu bersaing dengan sekolah dasar yang dikelola oleh Kementerian 
Pendidikan dan Kebudayaan (Steenbrink,1996: 34). Hal ini menunjukkan bahwa kompetisi peningkatan mutu antara sekolah umum dengan madrasah terjadi dan terbukti setelah adanya perubahan tersebut.

Namun demikian, sangat sedikit ditemui madrasah yang mampu berubah menjadi berkulitas. Sebaliknya, masih banyak madrasah yang belum atau belum mau atau tidak dapat berubah, sehingga tetap terpinggirkan dan tidak dapat bersaing dengan sekolah umum. Sebagai lembaga pendidikan Islam, banyak madrasah yang tidak mau berubah dan tetap ingin mempertahankan serta menjalankan fungsi-fungsi utamanya, antara lain sebagai sarana transmisi ilmu-ilmu keislaman, sarana menjaga dan memelihara tradisi-tradisi Islam, dan sarana mencetak ulama.

Bahkan ada juga beberapa madrasah yang tidak mau berubah dengan alasan menjaga tradisi/warisan nenek moyang pendiri madrasah tersebut, sementara menjadi bagian dari sistem pendidikan nasional dengan memasukkan bahan kajian sekurang-kurangnya tidak berbeda dengan sekolah umum dianggap merusak tradisi dan warisan para leluhur pendiri madrasah. Hal ini seperti yang disinyalir oleh Malik Fadjar, bahwa yang melatarbelakangi ketertinggalan madrasah adalah masih berorientasi ke masa lalu yang bercirikan konservatisme, dan kualitas pengelolaan yang rendah sehingga kurang professional, serta relevansi pendidikan Islam sendiri kurang mampu merespon tuntunan perkembangan baru yang riil (Fadjar, 1996: 27-30).

Saat ini, di antara sedikit madrasah yang telah dan sedang melakukan perubahan menjadi berkualitas dan mampu bersaing dengan sekolah-sekolah umum di wilayah Malang adalah Madrasah Ibtidaiyah Negeri I Malang (MIN I). MIN Malang 1 tidak hanya mampu bersaing dengan madrasah-madrasah lainnya di bawah naungan kementerian Agama, namun juga sekolah-sekolah umum di bawah naungan kemendikbud, bahkan prestasinya kadang-kadang melebihi dari sekolah-sekolah umum. Status berkualitas/unggulan dapat dilihat dari prestasi yang ditorehkan (Arifin, 1999). MIN Malang I misalnya, sebagai madrasah percontohan nasional, dan termasuk madrasah yang paling favorit di antara 6.533 madrasah Ibtidaiyyah yang ada di Jawa Timur memiliki banyak prestasi baik tingkat regional maupun nasional, bahkan internasonal, baik akademik maupun non-akademik. Di antaranya, MIN Malang I pernah menyabet juara I UKS tingkat nasional, juara I lomba lukis tingkat Jawa Timur, nasional, bahkan internasonal di New Delhi India. Masih banyak lagi prestasi dari MIN Malang 1 baik prestasi akademik maupun non akademik yang tidak mungkin tidak dapat disebutkan disini.

Namun sebutan berkualitas/unggulan itu tidak muncul begitu saja tanpa didahului oleh perjuangan dan proses yang cukup panjang dengan melakukan perubahan-perubahan (Hosking \& Marie, 1998). Berdasarkan paparan Bapak H. Abdul Jalil (Kepala MIN Malang I mulai tahun 1986-1994) pada buku “jejak-jejak Menjadikan Sekolah Unggul di Kota Malang; diperoleh 
penjelasan perubahan-perubahan dan pengembangan-pengembangan dilakukan, mulai dari membersihkan lingkungan yang asalnya kumuh menjadi bersih sampai dengan melakukan perubahan organisasi madrasah, mengelola perubahan tersebut, mengelola keuangannya, membenahi kurikulum, pengajaran, administrasi, sistem evaluasi, dan perpustakaan sampai dengan kesejahteraan guru dan tenaga administarsi.

Dari gambaran fenomena di atas, muncul sebuah pertanyaan (masalah), mengapa ada madrasah yang berkualitas, namun ada juga yang tidak berkualitas. Pertanyaan berikutnya adalah, mengapa madrasah-madrasah -dengan ciri-ciri rendahan tersebut- berkualitas dan menjadi unggulan di tingkatannya masing-masing, sementara madrasah yang lain tidak berkualitas, apalagi menjadi unggulan, padahal sudah terdapat persamaan kesempatan antara madrasah dan sekolah untuk berkembang. Tentunya ada perubahan-perubahan yang dilakukan oleh madrasah-madrasah tersebut yang tidak hanya menyangkut perubahan fisik tapi juga non fisik.

Berdasarkan studi yang dilakukan oleh Frymier diperoleh kesimpulan bahwa perubahan merupakan upaya memecahkan permasalahan yang dihadapi. Oleh karena itu, apabila dihubungkan dengan fungsinya sebagai institusi sosial terbuka, maka sekolah memang dituntut untuk selalu mengadakan perubahan-perubahan untuk memenuhi harapan-harapan dan tuntutan masyarakat yang selalu berubah. Apabila sekolah tidak mampu mengadakan perubahanperubahan yang sesuai, maka sekolah tidak akan mampu hidup relatif lebih lama (Frymier, dkk., 1984). Henderson dan Perry (1987) mengatakan bahwa sekolah yang baik adalah sekolah yang mampu mengadakan perubahan-perubahan. Dengan demikian, madrasah dan sekolah sebagai institusi sosial mesti melakukan perubahan bilamana menghendaki bertahan dalam rangka memenuhi ekspektasi masyarakat yang selalu berkembang.

Hasil penelitian Borko, Wolf, Simone \& Uchiyama (2003: 171-202) menunjukan bahwa kepemimpinan memegang peranan penting, atau menjadi faktor utama yang mendorong kesuksesan upaya-upaya reformasi dan perubahan sekolah. Fullan (1993) dalam penelitiannya menemukan hasil bahwa kepala sekolah merupakan agen bagi perbaikan sekolah. Putter menyimpulkan, sebagaimana dikutip oleh Sergiovanni, bahwa kepala sekolah adalah kunci keberhasilan untuk meningkatkan kualitas lulusan (Sergiovanni, 1987). Penelitian-penelitian di atas berdasar pada asumsi bahwa kepala madrasah atau sekolah merupakan pemimpin dan agen perubahan sekolah yang paling vital.

Berdasarkan penelitian di atas dapat diasumsikan bahwa prestasi yang diraih oleh madrasah-madrasah tersebut banyak ditentukan oleh kepala madrasah sebagai agen perubahan, walaupun pencapaian prestasi tersebut bersifat tidak langsung. Dalam penelitianya, Leithwood \& Riehl (2003), Hill (2002), Leithwood, Louis, K., Anderson, S.\& Wahlstrom (2004), Leithwood, 
A. K. \& Jantzi, D. (1997, 2000, 2003) menyimpulkan bahwa yang menentukan prestasi sekolah secara keseluruhan, termasuk prestasi siswa sebagai fokus utama sekolah adalah kepala sekolah. Lebih jelasnya mereka memberikan keterangan:

Dampak dari kepemimpinan pendidikan bagi pencapaian belajar siswa dipastikan ada. Akan tetapi efeknya tidak secara langsung dan tampak berfungsi melalui perbaikan-perbaikan variabel organisasi, seperti misi atau tujuan sekolah dan kurikulum dan pembelajaran. Ketika pendekatan kuantitatif mengestimasi bahwa efeknya tidak selalu kelihatan (dalam angka), variabel-variabel kepemimpinan sungguh bisa menjelaskan proporsi penting tentang varian yang terkait dengan sekolah dalam pencapaian hasil belajar siswa.

Meskipun efeknya tidak secara langsung, tetapi eksistensinya signifikan. Dalam review mereka tentang bagaimana kepemimpinan mempengaruhi belajar siswa, Leithwood: 2005) mengungkapkan:

Dari semua faktor yang berpengaruh terhadap belajar siswa di Sekolah, bukti yang ada menggiring kita untuk berkesimpulan bahwa kepemimpinan hanya berada di bawah satu tingkat dari pembelajaran di kelas.

Meskipun studi-studi tentang kepemimpinan sekolah (Harris, C. Day. 2005) sudah banyak dilakukan dengan menghasilkan karakteristik yang berbeda-beda, namun -sejauh pengetahuan peneliti, terutama hasil penelitian yang dapat dijangkau melalui media elektrikpenelitian tentang kepemimpinan pada proses perubahan yang mengambil lokus madrasah belum banyak dilakukan di Indonesia. Hal ini tentunya amat diperlukan untuk mengisi kekurangan tersebut dalam rangka untuk mengetahui sekaligus menemukan model dan karakteristik serta praktik-praktik kepemimpinan madrasah dalam mengelola perubahan di Indonesia. Di samping itu, penelitian kepemimpinan madrasah dapat bermanfaat untuk menambah informasi model kepemimpinan dalam konteks sekolah-sekolah di negara berkembang seperti Indonesia bahkan di kawasan Asia (Gurr, dkk., 2005).

Relevan dengan hal tersebut, Hill seorang ahli manajemen Inggris (Gill, 2003: 308) mengatakan bahwa kompleksitas problematika perubahan di organisasi sangat tergantung pada manajemen perubahan dan pola kepemimpinan perubahan. Good management of change is sinequa-non (manajamen perubahan yang baik adalah keharusan)", ungkap Gill. Gill melanjutkan while change must be well managed, it also requires effective leadership to be successfully introduced and sustained (di samping perlu dikelola dengan baik, perubahan juga memerlukan pemimpin yang efektif untuk memperkenalkan dan meningkatkan kualitasnya sehingga menjadi sukses). Oleh karenanya, adanya madrasah yang berkualitas perlu juga dilihat; apa saja nilainilai dan keyakinan yang mendasari pemimpin madrasah dalam meningkatkan kualitas madrasah sehingga menjadi sukses dan bagaimana nilai-nilai dan keyakinan tersebut mewujud dalam kepemimpinanya?. 


\section{METODE PENELITIAN}

Penelitian ini memiliki fokus apa saja nilai-nilai dan keyakinan yang mendasari pemimpin madrasah dalam meningkatkan kualitas madrasah sehingga menjadi sukses dan bagaimana nilai-nilai dan keyakinan tersebut mewujud dalam kepemimpinanya dan bertujuan untuk memperoleh pemahaman (to understand) secara mendalam tentang hal tersebut, maka penelitian ini didekati dengan kualitatif dengan jenis studi kasus. Madrasah dipilih sebagai subyek penelitian karena sebagaian besar penelitian sekolah sukses di Indonesia masih mengambil lokus jenis pendidikan umum, yaitu sekolah, sementara yang mengambil setting madrasah sangat terbatas.

Data tentang nilai-nilai dan keyakinan kepala madrasah sukses mengandung peristiwaperistiwa yang sangat komplek, bersifat holistik, natural, dan multimakna, maka peneliti menggunakan desain studi kasus. Dalam desain tersebut, suatu gaya studi kasus dengan banyak perspektif dilakukan dengan menyeleksi sumber-sumber data yang bervariasi (Yin: 1994: 130).

Dalam pengumpulan data peneliti akan menggunakan tiga tehnik, yaitu observasi partisipan (participant observation), wawancara mendalam (indepth interview), dan studi dokumen (Bogdan \& Biklen, 2003: 65). Pada dasarnya wawancara dilaksanakan secara simultan dengan pengamatan dan studi dokumentasi. Wawancara kadang juga merupakan kelanjutan dari pengamatan atau sebaliknya, begitu juga dengan simultansi antara wawancara dengan dokumentasi, pengamatan dengan dokumentasi.

Proses berikutnya adalah penelaahan dan penyusunan semua transkrip hasil wawancara, field note dan material-material penelitian yang lain secara sistematis atau yang biasa disebut dengan proses analisis data (Bogdan \& Biklen, 2003: 70). Oleh karena itu, proses ini dilakukan dalam rangka untuk menguji, mengkategori, mentabulasi dan mengkombinasi kembali buktibukti empiris untuk membangun proposisi-proposisi awal suatu penelitian (Yin, 1994: 125). Oleh karena itu, peneliti menelusuri dan mengelola secara sistematis hasil wawancara, catatan lapangan, dan data-data lain yang telah dikumpulkan oleh peneliti. Kegiatan ini dilakukan dengan menganalisis data, menata, mengelompokkan menjadi bagian-bagian yang dapat dikelola, mensistesis, menelusuri pola, selanjutnya ditemukan apa yang bermakna, dan apa yang diteliti dan dilaporkan secara runtut dan rinci. Agar dapat menafsirkan dan menginterpretasi data dengan baik maka proses ini harus dilakukan dengan tekun, teliti, sabar, dan kreatif sehingga dapat memperoleh makna pada setiap data yang ada atau informasi (Huberman, 1984).

Untuk memeriksa keabsahan (trustworthiness) data diukur dengan empat indikator sebagaimana dianjurkan oleh Lincoln dan Guba (1985: 331), yaitu: (1) derajat kepercayaan (credibility), (2) keteralihan (transferability), (3) kebergantungan (dependability), dan (4) kepastian (confirmability). 


\section{HASIL DAN PEMBAHASAN}

Penelitian ini ingin melihat proses-proses yang baik di madrasah dan out put siswa yang berkualitas, dengan fokus pada prestasi yang akademik maupun non akademik merefleksikan nilai-nilai dan keyakinan profesional. Nilai-nilai spiritual kepala madrasah terefleksikan pada komitmen madrasah pada agama dan moralitas dan animo serta kepercayaan masyarakat agar anaknya dapat sekolah di lembaga yang identik dengan nilai-nilai agama, yaitu madrasah. Sementara itu, nilai-nilai hubungan kemanusiaan direfleksikan dalam proses-proses madrasah yang berkualitas melalui kepemimpinan yang kuat dan terciptanya kondisi-kondisi madrasah yang baik dan mendukung.

Dengan demikian, keberhasilan sebuah madrasah dapat mencerminkan nilai serta keyakinan yang dimiliki kepala madrasah mengenai sesuatu yang mestinya dicapai oleh madrasah. Di samping itu, nilai dan keyakinan sangat berpengaruh terhadap praktik kepemimpinan kepala sekolah/madrasah dalam mengembangkan dan mengubah madrasah menjadi lebih baik, mulai dari proses-proses dan prosedur-prosedur kepemimpinannya. Hal ini sejalan dengan temuan penelitian terdahulu tentang kepemimpinan moralis, bahwa nilai merupakan hal pokok bagi praktik-praktik kepemimpinan dan administrasi. Kepala sekolah moralis membawa sekolah menuju sebuah visi atau tujuan dengan penuh keyakinan bahwa mereka berdiri di atas nilai-nilai moral dan edukasional yang penting (Leithwood \& Duke, 1999). Dengan demikian, kepemimpinan moralitas terutama didasarkan pada nilai-nilai dan etika pemimpin, yang tercermin dalam praktik-praktik kepemimpinan. Dimensi kepemimpinan ini sangat vital dalam konteks pendidikan, karena sebagaimana ditunjukkan oleh Duignan, Bhindi \& Pherson, 1993: 4), terdapat jurang kejujuran dan integritas dalam praktik-praktik kepemimpinan masa kini (kasus contek massal yang terlihat dalam hal ini). Tuntutan-tuntutan material dapat menyebabkan pemimpin melupakan aspek-aspek etis dari kepemimpinan.

Nilai-nilai dan keyakinan-keyakinan yang melandasi kepala sekolah/madrasah dalam mengelola perubahan di MIN Malang 1 diklasifikasi menjadi nilai-nilai dan keyakinan religius, profesional dan kemanusiaan. Nilai-nilai dan keyakinan religius yang kuat dari kepala madrasah banyak terartikulasikan dalam proses-proses sekolah. Pada kasus penelitian ini, nilai-nilai dan keyakinan religius yang dimiliki kepala madrasah adalah optimis dan percaya diri, ikhlas dan tawakkal, rendah hati (tawadlu) dan empat sifat Rasul yaitu jujur/shiddiq, amanah, tabligh, dan fathonah. Sebagaimana yang terdapat pada tabel 1 berikut ini: 
Tabel 1: Nilai-Nilai dan Keyakinan Hidup

Nilai-Nilai dan Keyakinan Hidup

- Nilai religius; Optimis dan Percaya Diri; Ikhlas dan Tawakkal; Rendah Hati/Tawadlu; Empat Sifat Rasul; Jujur, Amanah, Tabligh, Fathonah

- Nilai profesional; Komitmen pada Pengembangan dan Perubahan; Disiplin; Cinta Prestasi dan Keunggulan; Berorientasi pada pengembangan siswa; dan Keteladanan

- Nilai Kemanusiaan; Kebersamaan; Respect/Menghargai Orang Lain; Empati dan Peduli.

\section{Nilai-Nilai dan Keyakinan Religius.}

Optimis dapat berarti keyakinan untuk mendapatkan sesuatu dari apa yang dikerjakan, karena apa yang dikerjakan pasti tidak akan sia-sia. Optimis berarti meyakini bahwa yang kita kerjakan untuk melakukan perubahan pasti berhasil. Dengan rasa optimis yang dimiliki oleh pimpinan akan menumbuhkan rasa optimis pula pada seluruh anggota madrasah, sehingga dapat berdampak pada kinerja 'kerja keras' untuk memperbaiki mutu madrasah.

Pada penelitian ini ditemukan, sikap optimis dan percaya diri kepala madrasah terinspirasi dari surat al-Ra'du ayat 11 yang berbunyi:

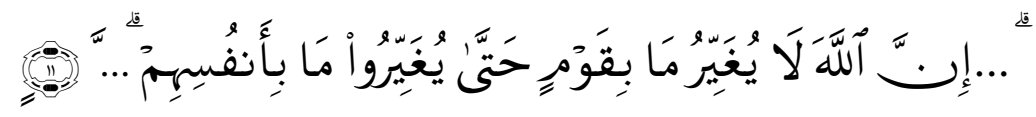

Artinya: "Allah tidak akan mengubah suatu kaum, sampai kaum tersebut mengubahnya sendiri".

Optimis juga diartikan dalam praktik kepemimpinan yang berani mengambil keputusan oleh kepala madrasah. Namun, nilai optimis yang diyakini kepala madrasah didukung oleh kreatifitas kepala madrasah dalam melakukan terobosan-terobosan. Nilai optimis ini sebagaimana yang tertuang dalam surat al-Qur'an Ali Imran: 191 yang berbunyi:

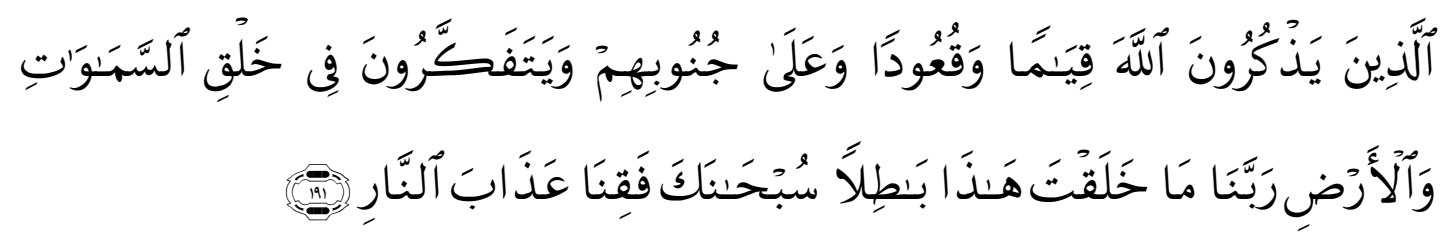

"Orang-orang yang mengingat Allah sambil berdiri atau duduk atau dalam keadan berbaring dan mereka memikirkan tentang penciptaan langit dan bumi (seraya berkata):

"Ya Tuhan Kami, Tiadalah Engkau menciptakan ini dengan sia-sia, Maha suci Engkau, Maka peliharalah Kami dari siksa neraka".

Ayat ini memberikan inspirasi kepada kepala madrasah bahwa setiap apa yang dikerjakan pasti tidak ada yang sia-sia. Dengan demikian, kesuksesan yang dilakukan pasti memberikan manfaat bagi kemajuan pendidikan di madrasah. Hal ini juga sesuai dengan 
semangat dari ayat al-Qur'an surat al-Zalzalah 6-7 yang artinya bahwa setiap upaya baik manusia akan memperoleh hasil.

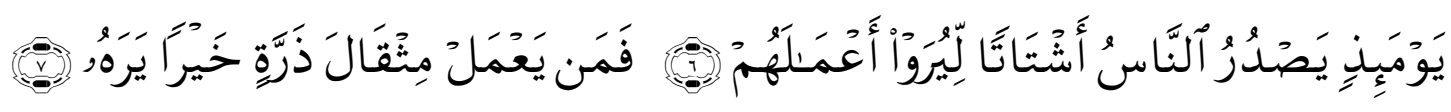

"Pada hari itu manusia keluar dari kuburnya dalam keadaan bermacam-macam, supaya diperlihatkan kepada mereka (balasan) pekerjaan mereka. Barangsiapa yang mengerjakan kebaikan seberat dzarrahpun, niscaya Dia akan melihat (balasan)-Nya".

Nilai berikutnya yang mendasari pola kerja kepala madrasah adalah ikhlas dan tawakkal. Tawakkal dapat berarti ia memiliki sikap menempatkan kepercayaan kepada Allah atas apapun yang telah dilakukan dalam perubahan. Kepala madrasah merasa harus berupaya secara maksimal untuk mencapai tujuan-tujuan madrasah, untuk selanjutnya hasil dari perubahan yang dilakukan diserahkan kepada yang Maha Kuasa. Pada kasus Penelitian ini, kepala madrasah mengambil ilustrasi logo kementerian agama yang mencantumkan kata ikhlas beramal; ikhlas dalam melakukan sesuatu. Dengan demikian, usaha inovasi yang dilakukan kepala madrasah tidak ada yang sia-sia dan harus disertai dengan hati yang ikhlas dan tawakkal. Dalam ayat al-Qur'an surat Ali Imran 159 disebutkan bahwa setelah berusaha dengan tekad bulat, maka hendaklah manusia bertawakkal dan berserahdiri kepada Allah. Ayat tersebut berbunyi:

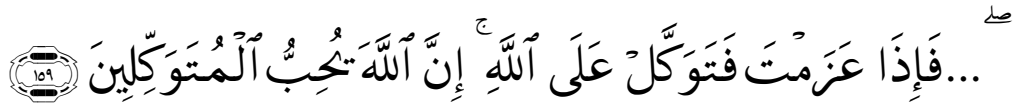

"Kemudian apabila kamu telah membulatkan tekad, Maka bertawakkallah kepada Allah. Sesungguhnya Allah menyukai orang-orang yang bertawakkal kepada-Nya”.

Rendah hati atau tawadlu' adalah juga nilai yang anut secara kuat oleh kepala madrasah ibtidaiyah, dan sangat berpengaruh kepada pola kepemimpinannya. Tawadlu dapat diartikan rendah hati, tidak sombong. Kepala madrasah adalah sosok yang rendah hati, tidak mau mengagungkan dirinya sendiri dan selalu menerima pendapat dan kritik orang lain. Nilai yang demikian menjadi ukuran kualitas kepemimpinan yang baik. Ia seringkali menyatakan bahwa dirinya harus banyak belajar dari orang lain atau lembaga lain. Dalam mengelola perubahan, kepala madrasah juga memiliki "kerendahan hati", dalam artitidak terlena oleh kesuksesan yang telah diraih dan senantiasa waspada terhadap bermacam perubahan situasi dan kondisi serta perkembangannya yang dapat mempengaruhi daya tahan dan daya saing serta masa depan madrasah.

Kepala madrasah juga mengambil nilai-nilai dari empat sifat Rasulullah, yaitu jujur, amanah, tabligh dan fathonah. Jujur atau shiddiq adalah menyampaikan sesuatu sesuai dengan kenyataan. Jujur juga dapat diartikan melakukan apa yang disampaikan. Kepala 
madrasah selalu menjadi uswatun hasanah dengan memberikan contoh terhadap apa yang disampaikan dan menyampaikan apa yang menjadi kenyataan. Termasuk kepala madrasah menentang keras praktik-praktik kecurangan pada Ujian Nasional sebagai bentuk praktik kejujuran yang beliau miliki sambil menyindir prilaku "contek massal” yang dianggap menciderai usaha membentuk karakter jujur anak didik selama 6 tahun. Sifat jujur kepala madrasah juga diartikan kesediaan kepala madrasah menerima koreksi terhadap kebijakan.

Pada temuan kasus, nilai yang diikuti kepala madrasah berikutnya adalah nilai amanah. Kepala madrasah meyakini bahwa tugasnya/jabatannya adalah amanah dari Allah dan masyarakat sekolah, oleh karenanya kepala madrasah selalu berkomitmen terhadap pekerjaannya, dan melaksanakan dengan penuh tanggungjawab. Mengenai amanah ini, Allah berfirman dalam surat al-Ahzab: 72 yang berbunyi:

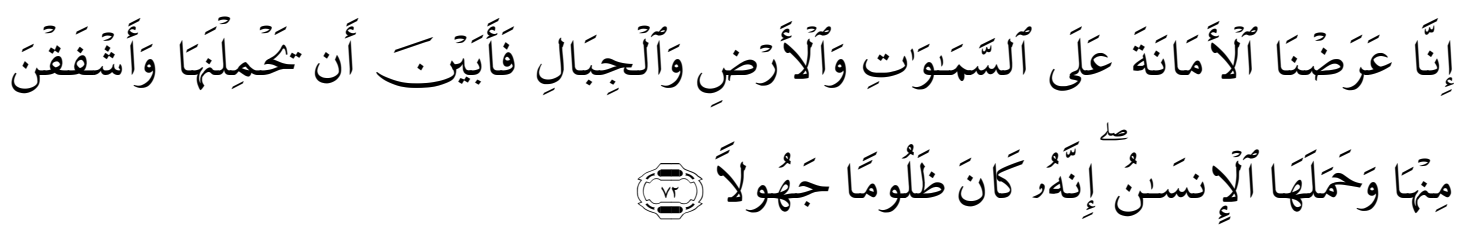

"Sesunggunnya Kamı telah mengemukakan amanat kepada langlt, bumı dan gununggunung, maka semuanya enggan untuk memikul amanat itu dan mereka khawatir akan mengkhianatinya, dan dipikullah amanat itu oleh manusia. Sesungguhnya manusia itu amat zalim dan amat bodoh".

Menurut Hamka sebagaimana dikutip oleh Rahardjo, ayat tersebut ingin menggambarkan secara majaz betapa berat amanah itu, sehingga gunung, bumi dan langit tidak berani dan tidak sanggup memikulnya. Dalam tafsir ini disampaikan bahwa hanya manusia yang dapat dan mampu mengemban amanah, karena memang manusia diberikan kekuatan itu oleh Allah, walaupun sebagian manusia kemudian berbuat dzalim, baik untuk dirinya sendiri, maupun orang lain. Manusia juga seringkali bertindak bodoh dengan mengkhianati amanah itu (Raharjo: 2002: 349).

Dalam kamus kontemporer karya Ali \& Mudlor (tt: 215) menurut amanah diartikan dengan kejujuran, kepercayaan (hal dapat dipercaya). Amanah merupakan salah satu sifat Rasul. al-Munawwar (2002: 197-199) mengungkapkan bahwa kekuasaan adalah amanah, oleh karena itu kekuasaan harus diemban dengan penuh amanah. Hal ini menyiratkan dua hal, pertama; kekuasaan manusia di muka bumi adalah bersifat relatif dan harus dipertanggungjawabkanya kelak dikemudian hari karena kekuasaan yang sebenarnya adalah milik Allah. Kekuasaan hanya bersumber dari Allah yang didelegasikan kepada umat manusia melalui tugas kekhalifaan. Kedua; karena kekuasaan itu amanah, maka pelaksanaannya pun membutuhkan amanah. Oleh karena amanah, maka harus diemban 
dengan penuh tanggungjawab, jujur, dan berpegang teguh pada prinsip-prinsip dan nilai yang harus diikuti.

Hal ini sesuai perintah Allah dalam al-Qur'an surat an-Nisa': 58 yang berbunyi:

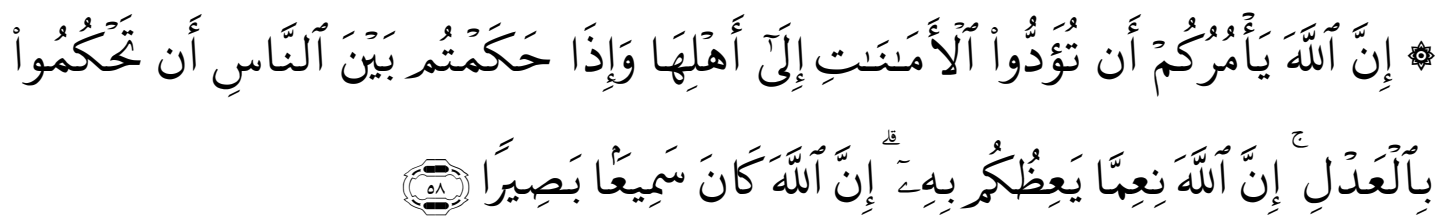

"Sesungguhnya Allah menyuruh kamu menyampaikan amanat kepada yang berhak menerimanya, dan (menyuruh kamu) apabila menetapkan hukum di antara manusia supaya kamu menetapkan dengan adil. Sesungguhnya Allah memberi pengajaran yang sebaik-baiknya kepadamu. Sesungguhnya Allah adalah Maha Mendengar lagi Maha Melihat"

Tanggungjawab di sini bukan hanya kepada manusia, tetapi juga karena Allah. Kepada lembagamadrasah, amanah ditunjukkan dengan selalu menyampaikan laporan pertanggungjawaban kepada Kementerian Agama (Mapenda), selain kepada walimurid melalui komite madrasah.

Pada kasus penelitian ini, amanah bagi kepala madrasah adalah memberikan yang terbaik dalam mengelola madrasah sebagai bentuk tanggungjawab mengemban amanah dari apa yang diamanahkan kepada kepala madrasah. Amanah menurut kepala madrasah adalah sebagai bentuk dakwah islamiyah dan tidak hanya mencapai tujuan pendidikan saja. Amanah tampak merata di kalangan komunitas madrasah dan kepala madrasah sebagai orang yang berkomitmen dan dapat dipercaya sebagai akibat dari keyakinan kuatnya akan amanah.

Amanah ini diindikasikan sebagai bentuk model manajemen, menyusun program kerja secara bersama, memberikan kepercayaan kepada bawahannya untuk mengelola program perubahan dan kegiatan, termasuk keuangan, kerja keras dalam pelaksanaan, pengendalian untuk mengawal tugas-tugas dan mengevaluasi secara keseluruhan. Jadi amanah sebagai bentuk kelebihan yang mewujud dalam praktik-praktik kepemimpinannya. Bahkan kedisiplinan yang tidak pernah datang terlambat di madrasah (kecuali ada acara) dan pulang selalu akhir adalah bentuk sikap amanah sebagai kepala madrasah yang selalu memberi contoh kepada bawahannya.

Nilai dari tablih diartikan dengan selalu menyampaikan kebijakan-kebijakan kepada para anggota madrasah dengan tidak bosan. Bahkan seringkali kepala madrasah mengajak sharing dengan para bawahannya untuk menentukan kegiatan-kegiatan madrasah, seperti ketika memformulasikan visi, misi, dan kegiatan untuk pelayanan kesiswaan. Tabligh juga dapat berarti selalu menyampaikan kebaikan dan melarang kemunkaran. Penyebaran visi 
secara terus menerus adalah juga bagian dari kegiatan tabligh, agar anggota madrasah selalu berada pada track visi dan misi madrasah. Hal ini seperti yang disampaikan oleh al-Qur'an surat al-Hijr: 94-95, bahwa menyeru kepada kebaikan perlu disampaikan secara terangterangan. Kepala madrasah sebagai penyampai visi dan misi madrasah tidak perlu takut dan sembunyi-sembunyi. Sebab, sebetulnya terdapat jaminan lindungan dari Allah swt bagi orang yang menyampaikan visi madrasah. Al-Qur'an surat al-Hijr: 94-95 menyebutkan:

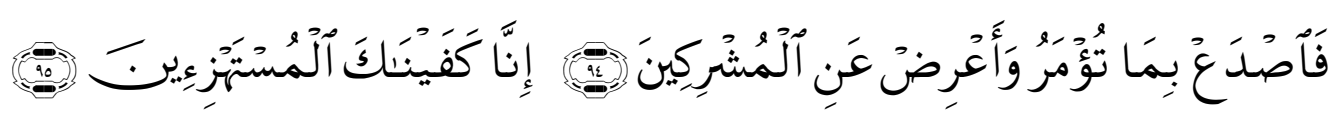

мака sатралкапıаn оьепти secara terang-terangan segaıa apa yang aıperıntanкan (kepadamu) dan berpalinglah dari orang-orang yang musyrik. Sesungguhnya Kami memelihara kamu daripada (kejahatan) orang-orang yang memperolok-olokkan (kamu).

Dalam istilah pendekatan manajemen, apa yang dilakukan oleh kepala madrasah dengan selalu menyampaikan kebijakan dan mengajak para bawahan menyelesaikan problem organisasi termasuk kategori open management. Pada kasus Penelitian ini, kepala madrasah berharap para anggota madrasah untuk mengingat visi, misi dan tujuan madrasah, dan selalu ada di otak dan kepala seluruh komunitas madrasah.Nilai tabligh ditunjukkan dengan selalu menyampaikan hal-hal baik kepada seluruh komunitas madrasah di setiap kesempatan.

Nilai fathonah atau cerdas memang dipunyai oleh kepala madrasah. Kecerdasan di sini nampak pada kreatifitas dan inovatifitas kepala madrasah, mengeluarkan pendapat, ide dan gagasan pembaharuan bagi kesuksesan organisasinya. Nilai ini juga yang dimiliki oleh kepala madrasah, sehingga beliau terpilih menjadi kepala madrasah ter-kreatif dan terinovatif tingkat nasional tahun 2010. Kecerdasan kepala madrasah juga ditunjukkan dengan kemampuannya membuat ide dan gagasan baru. Keberhasilan kepala madrasah mendapatkan penghargaan sebagai kepala madrasah terinovatif dan terkreatif serta kepercayaan sebagai ketua program akselerasi adalah merupakan anugerah dan keistimewaan dari Allah swt dibanding dengan orang lain. Begitulah, Allah swt juga memberikan kelebihan dan keistimewaan kepada Thalut dengan mengangkatnya menjadi Raja. Surat al-Baqarah: 247 menggambarkan hal tersebut:

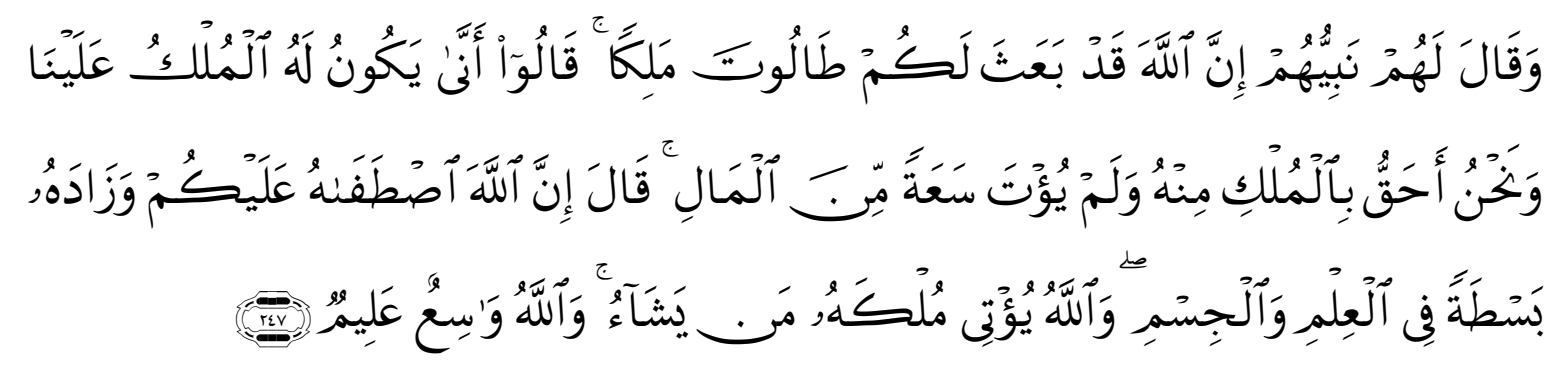


Nabi mereka mengatakan kepada mereka: "Sesungguhnya Allah telah mengangkat Thalut menjadi rajamu." mereka menjawab: "Bagaimana Thalut memerintah Kami, Padahal Kami lebih berhak mengendalikan pemerintahan daripadanya, sedang diapun tidak diberi kekayaan yang cukup banyak?" Nabi (mereka) berkata: "Sesungguhnya Allah telah memilih rajamu dan menganugerahinya ilmu yang Luas dan tubuh yang perkasa." Allah memberikan pemerintahan kepada siapa yang dikehendaki-Nya dan Allah Maha Luas pemberian-Nya lagi Maha mengetahui.

Kepala madrasah harus cerdas dalam organisasinya sebagai sarana untuk meningkatkan keuntungan kompetitif madrasah yang dikelolanya. Kepala madrasah harus bisa menggambarkan perubahan itu secara nyata dipikiran setiap orang, dan memberikan cermin perubahan sehingga dapat dilihat wujud sesungguhnya dari perubahan tersebut oleh semua orang. Rasulullah dalam sebuah hadisnya mengatakan:

Sekiranya hari Kiamat itu sudah diambang pintu terjadinya, dan adalah sebiji korma di dalam genggaman tanganmu, dan kamu masih punya sekedar waktu untuk menanamkan biji itu, maka tanamkanlah. Engkau akan memperoleh pahala karenanya.

Kepala madrasah harus cerdas. Dengan kecerdasan yang dimiliki diharapkan kepala madrasah mampu berfikir cepat, bertindak cepat, kreatif, inovatif serta mampu menyelesaikan masalah secara adil dan bijaksana. Pemimpin tidak boleh hanya sekedar berwacana, tapi harus berbuat dan mencoba untuk selalu melakukan pembaharuan.

\section{Nilai-Nilai dan Keyakinan Profesional.}

Di samping nilai yang bersifat personal, pada kasus ini juga ditemukan nilai-nilai yang bersifat profesional. Pada kasus penelitian ini, kepala madrasah memiliki komitmen kuat pada perubahan dan pengembangan, disiplin, cinta pada kesuksesan/prestasi, dan berorientasi pada pengembangan siswa.

Kepala madrasah memiliki komitmen tinggi untuk selalu melakukan perubahan. Perubahan diyakini oleh kepala madrasah sebagai sesuatu yang semestinya dilakukan bilamana madrasah ingin tetap bertahan di era globalisasi, sebagaimana keyakinan yang terdapat pada diri kepala madrasah dan berdasar kepada al-Ra'du serta harus berangkat dari visi dan misi. Kepala madrasah juga mempunyai gagasan-gagasan inovatif untuk membuat perubahan dan pengembangan Penelitian ini, seperti mengadakan kegiatan MSC (Mathematic and Science Club). Kegiatan ini dipersiapkan bagi siswa-siswa MIN yang akan mengikuti lomba Sains dan Matematika. Dalam pembelajaran, kepala madrasah juga sangat kuat mendorong guru-guru untuk selalu mengadakan perubahan dan inovasi dalam rangka untuk meningkatkan kualitas pembelajaran.

Sejalan dengan literatur tentang kepemimpinan instruksional, temuan pada penelitian ini menggambarkan, kepala madrasah juga memiliki orientasi untuk pengembangan siswa (Glickman, Gordon \& Ross-Gordon, 2001). Kepala madrasah percaya bahwa siswa adalah 
subyek utama dan terutama dalam pembelajaran dan pendidikan. Oleh karena itu, programprogram madrasah diorientasikan pada pengembangan dan pembinaan siswa dengan memberikan wadah bagi anak-anak didik yang berminat sekaligus melakukan pembinaan terhadap anak-anak yang berbakat.

Pengakuan atas hasrat untuk melayani orang lain, peduli pada kepentingannya di atas kepentingan dirinya sendiri. Melayani orang lain dengan tulus ikhlas adalah satu kunci kesempurnaan spritualitas seseorang. Allah swt telah berfirman dalam surat Ali Imran: 159 sebagai berikut:

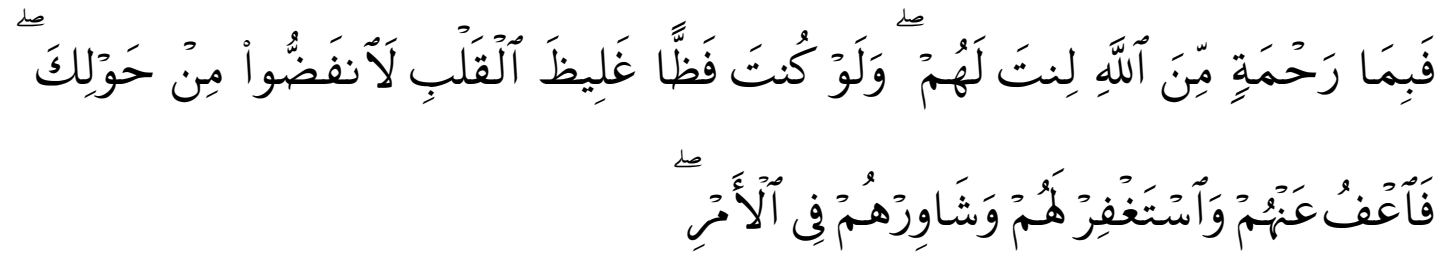

Maka disebabkan rahmat dari Allah-lah kamu Berlaku lemah lembut terhadap mereka. Sekiranya kamu bersikap keras lagi berhati kasar, tentulah mereka menjauhkan diri dari sekelilingmu. karena itu ma'afkanlah mereka, mohonkanlah ampun bagi mereka, dan bermusyawaratlah dengan mereka dalam urusan itu...

Fokus pada pelanggan yaitu melayani kepentingan siswa mengandung prinsip bahwa semua kegiatan pendidikan dan pembelajaran harus memposisikan siswa sebagai subyek utamanya.

Pada kasus penelitian ini, kegiatan pengembangan dan pembinaan siswa diarahkan pada prestasi yang dihasilkan siswa. Demikian pula, perubahan-perubahan yang dilakukan, baik yang bersifat akademik maupun non-akademik adalah dalam rangka untuk mencapai kesuksesan dan prestasi siswa. Sehingga, kepemimpinan kepala madrasahpun diorientasikan bagi pengembangan dan melahirkan siswa-siswa yang berprestasi. Kepala madrasah sangat memperhatikan pentingnya cita-cita dalam mengelola madrasah. Baginya, cita-cita atau harapan adalah kunci untuk dapat mengembangkan madrasah.

Apa yang diperbuat oleh kepala madrasah di atas adalah merupakan bentuk pelayanan yang sebaik-baiknya yang ingin diberikan oleh kepala madrasah kepada para stakeholder. Pelayanan dalam berbagai bentuknya, apakah membantu memudahkan urusan orang lain (siswa) atau bahkan melayani merealisasikan gagasan-gagasan besar seperti visi dan misi madrasah, adalah buah dari penempaan spritual individu. Pelayanan adalah sebuah peribadatan agung yang mencerminkan kesalehan individu (kepala madrasah) yang sebenarnya. Oleh karenanya, pelayanan kepada siswa dan stakeholder adalah bagian penting dari keimanan seseorang kepada Allah. Rasulullah Muhamad saw mengatakan: 


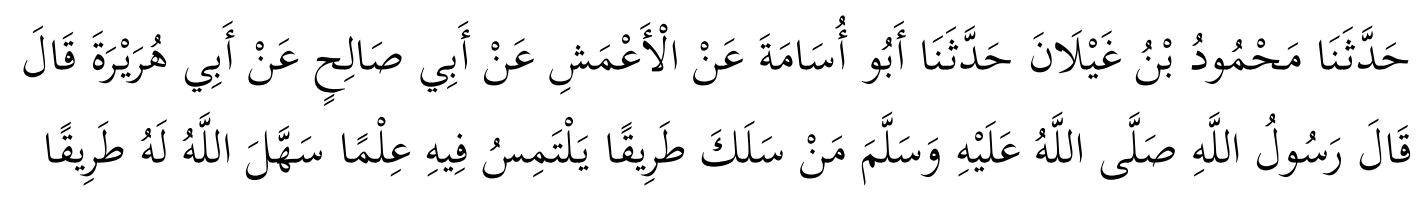

Telah diceritakan dari Mahmud bin Ghailan, telah diceritakan dari Abu Usamah dari A'masy dari Abi Shalih dari Abi Hurairah berkata. Rasulullah saw berkata; Barang siapa mempermudah jalan seseorang dalam mencari ilmu, maka juga akan meтpermudah baginya jalan menuju surga.

Kepala madrasah pada penelitian ini, juga meyakini bahwa disiplin merupakan kunci keberhasilan dan merupakan hal yang urgen dalam kesuksesan dalam dunia pendidikan. Dalam surat al-'Ashr, kedisiplinan seringkali diumpamakan dengan penghargaan terhadap "masa/waktu".

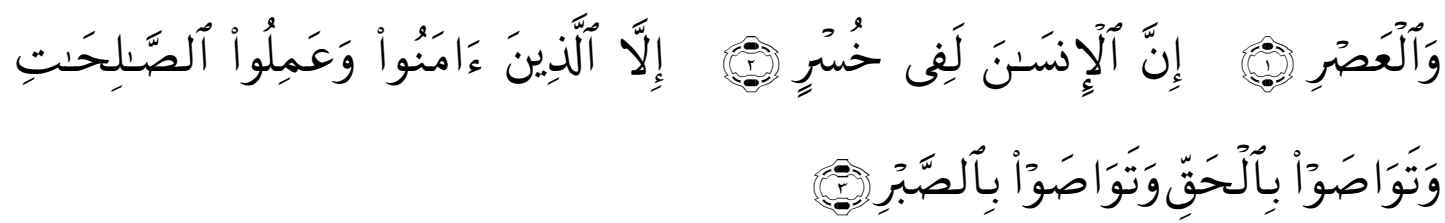

(1) Demi masa, (2) Sesungguhnya manusia itu benar-benar dalam kerugian, (3) Kecuali orang-orang yang beriman dan mengerjakan amal saleh dan nasehat menasehati supaya mentaati kebenaran dan nasehat menasehati supaya menetapi kesabaran.

Keyakinan dan nilai-nilai disiplin yang dimiliki kepala madrasah menjadikan inspirasi dalam berbagai aktifitas persekolahan. Pada kasus Penelitian ini misalnya, kepala madrasah mencontohkan kedisiplinan administrasi, jurnal, presensi, RPP, dan beliau mencontohkan untuk dimulai dari diri sendiri.

Budaya disiplin juga dicontohkan langsung oleh kepala madrasah. Hampir setiap hari, Ia selalu datang sebelum jam 06.00 untuk memantau kehadiran siswa, guru dan karyawan. Beliau juga pulang setelah sekolah akan tutup. Contoh yang diberikan kepala madrasah ini ternyata sangat berpengaruh terhadap kedisiplinan para siswa, guru dan karyawan. Kedisiplinan yang tidak pernah terlambat ini menunjukkan bahwa nilai disiplin telah menjadi karakter selalu mewarnai dalam pola kepemimpinan di Penelitian ini.Dengan demikian, kepala madrasah selalu bersikap disiplin dan berusaha mendisiplinkan anggota madrasah yang lain. Menegakkan kedisiplinan bahkan merupakan salah satu strategi kepemimpinan dalam rangka untuk mengembangkan dan mengubah madrasah yang dipimpinnya. Kepala madrasah juga memberikan suri tauladan dengan mencontohkan kedisiplinan.

Keteladan atau uswatun hasanah memang merupakan nilai dan keyakinan profesional yang harus dimiliki oleh kepala madrasah dan sekaligus yang mendasari keseluruhan aktifitas mengelola madrasah. Keteladanan di sini adalah keselarasan antara 
perkataan dan perbuatan. Artinya, apa yang dikatakan hendaknya juga dilakukan. Kepala madrasah mengedepankan keteladanan, yaitu sedikit bicara dan banyak bekerja serta diimbangi dengan konsisten dan disiplin. Keteladanan yang dicontohkan oleh kepala madrasah dalam hal kedisiplinan. Kepala madrasah sangat berkeyakinan bahwa disiplin adalah kunci keberhasilan. Oleh kepala madrasah disiplin harus dimulai dari diri sendiri, baik kedisiplinan dalam hal ketertiban administrasi, jurnal, RPP dan sebagainya. Di dalam meneladani apa yang beliau katakan atau programkan, kepala madrasah menggunakan slogan "ibda' bi nafsika" yang artinya mulailah dari dirimu sendiri. Dengan demikian, sebelum mengubah orang lain kepala madrasah memulai perubahan dari dirinya sendiri. Tujuannya adalah agar tujuan perubahan dan ajakannya berpengaruh kepada anggota madrasah. Allah swt dalam al-Anfal; 53 bersabda:

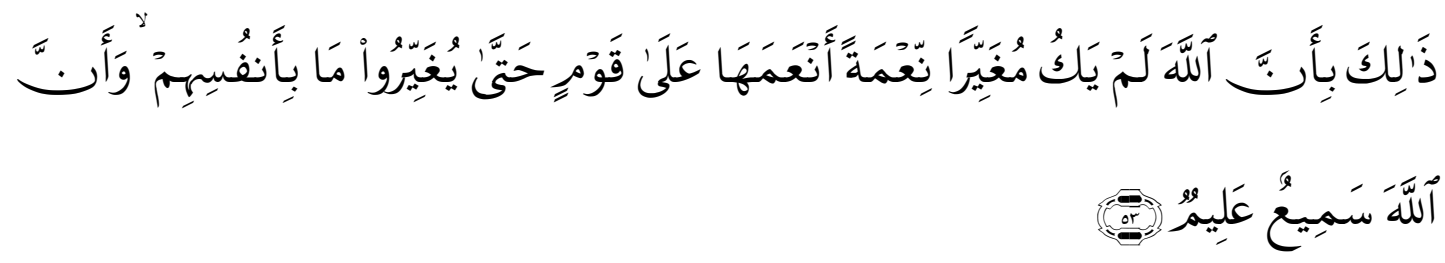

(Siksaan) yang demikian itu adalah karena Sesungguhnya Allah sekali-kali tidak akan meubah sesuatu nikmat yang telah dianugerahkan-Nya kepada suatu kaum, hingga kaum itu mengubah apa-apa yang ada pada diri mereka sendiri, dan Sesungguhnya Allah Maha mendengar lagi Maha mengetahui.

Temuan lain adalah kepala madrasah memiliki orientasi pada cinta keunggulan dan prestasi. Kepala madrasah percaya bahwa dengan selalu berfikir prestasi, di kepala dan di dada, apalagi itu dicantumkan pada salah satu visinya, maka cinta keunggulan dan prestasi selalu mewarnai setiap aktifitas kepala madrasah. Cinta keunggulan dan prestasi di sini tidak hanya sekedar berprestasi tetapi lebih kepada keunggulan. Cinta keunggulan dicirikan tidak hanya sekedar melakukan tetapi juga harus berkualitas. Nilai-nilai ini sangat berpengaruh pada pola kepemimpinan kepala madrasah. Prestasi dan keunggulan di sini tidak hanya sekedar menjuari lomba atau pertandingan, tetapi juga keunggulan dalam segala hal. Unggul pembelajaran, unggul administrasi, unggul akademik dan non akademik, unggul sarana prasarana, unggul proses dan sebagainya.

Orientasi untuk selalu berprestasi dan menjadi yang paling ungul menunjukkan kepedulian akan mutu. Dalam praktik ini, pada diri kepala madrasah melekat dimensi spritual, yakni hasrat atau dorongan untuk meraih kesempurnaan (perfection). Kebenaran, kebaikan dan keindahan adalah dimensi-dimensi dari kesempurnaan dan keunggulan. Surat al-Maidah; 100 menggambarkan perbedaan antara kerja berkualitas dengan tidak berkualitas: 


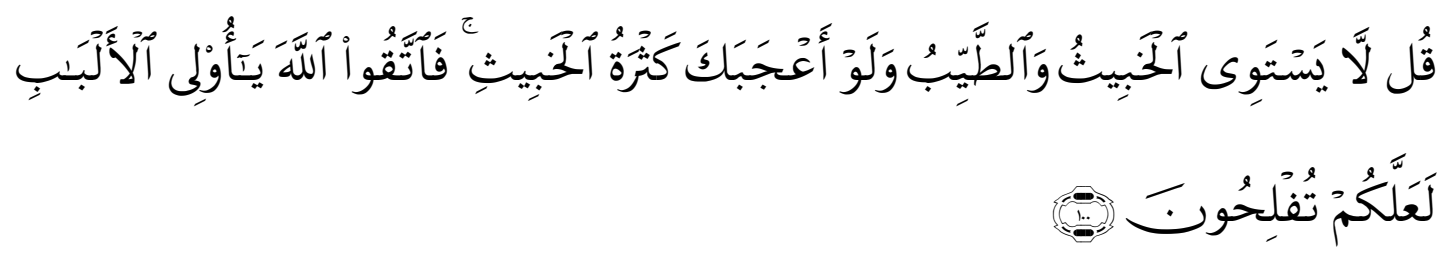

Katakanlah: "tidak sama yang buruk dengan yang baik, meskipun banyaknya yang buruk itu menarik hatimu, Maka bertakwalah kepada Allah Hai orang-orang berakal, agar kamu mendapat keberuntungan.

Prinsip yang berlaku dalam konsep quality adalah memberikan lulusan-lulusan yang terbaik dan berkualitas, baik secara akademis maupun non akademis yang secara terusmenerus melampaui harapan-harapan stakeholder dan pengguna.

Sementara itu, temuan lain pada kasus penelitian adalah sikap terbuka dalam kepemimpinan kepala madrasah. Kepala madrasah sangat terbuka kepada komunitas madrasah, termasuk dalam hal anggaran. Sikap keterbukaan kepala madrasah juga ditunjukkan dengan sikap sangat percaya kepada bawahanya untuk mengelola tugas dan tanggungjawab yang diberikan kepada bawahannya. Kepala madrasah memberikan keleluasaan kepada bahawannya untuk berkreasi dan mengembangkan program sesuai dengan tugas dan tanggungjawabnya. Prilaku kepemimpinan dalam mengelola perubahan dilandasi oleh nilai keterbukaan dengan mengindikasikan kepercayaan kepala madrasah terhadap staf-stafnya untuk kreatif dan selalu berinovasi sesuai dengan tugasnya masingmasing. Praktik kepemimpinan yang terbuka, memberikan kepercayaan yang tinggi terhadap bawahannya.

Keteladan atau uswatun hasanah merupakan nilai dan keyakinan profesional lain yang disebutkan kepala madrasah sebagai kualitas yang dimiliki, sekaligus yang mendasari keseluruhan aktifitas mengelola madrasah. Keteladanan yang dimaksud di sini adalah keselarasan antara perkataan dan perbuatan. Artinya, apa yang dikatakan hendaknya juga dilakukan. Kepala madrasah mengedepankan keteladanan, yaitu sedikit bicara dan banyak bekerja serta diimbangi dengan konsisten dan disiplin.

\section{Nilai-Nilai dan Keyakinan Humanis}

Nilai profesional lain yang berhasil ditemakan oleh peneliti adalah nilai kemanusiaan. Yang dimaksud dengan nilai dan keyakinan kemanusiaan di sini adalah bagaimana kepala madrasah menempatkan orang lain dalam praktik kepemimpinannya untuk mengelola perubahan. Pada kasus Penelitian ini prinsip yang diyakini adalah bagaimana kita dapat mengakui persamaan dengan orang lain untuk kebersamaan, apresiatif terhadap orang lain, respek, dan peduli terhadap orang lain. 
Persamaan diorientasikan sebagai nilai yang diyakini kepala madrasah dan sangat berpengaruh pada praktik kepemimpinan kepala madrasah dalam mengelola perubahan. Kebersamaan ini dapat muncul jika pemimpin memiliki sikap dan melihat eksistensi diri sebagai bagian dari eksistensi setiap anggota organisasi, dan bukan sebaliknya. Kebersamaan diartikan bahwa orang lain memiliki posisi dan potensi yang sama dengan kepala madrasah. Setiap anggota madrasah memainkan peranan yang sama dan penting dalam proses pengubahan madrasah serta memiliki peran yang sama sesuai dengan posisinya masing-masing. Kepala madrasah mengumpamakan anggota madrasah seperti anggota tubuh yang masing-masing berperan sesuai dengan peranya dan bertangungjawab kepada lainya sehingga dapat saling menghargai.

Fondasi perubahan adalah persaudaraan dan kebersamaan. Anggota madrasah ibarat satu keluarga yang saling menguatkan. Hidup bersaudara adalah kenikmatan yang dianugerahkan oleh Allah swt kepada orang-orang yang beriman. Karena itulah, persaudaraan merupakan konsekuensi logis dari keimanan sesorang yang tidak dapat dipisahkan satu dengan yang lain. Al-Qur'an surat Ali Imran: 103 menyebutkan:

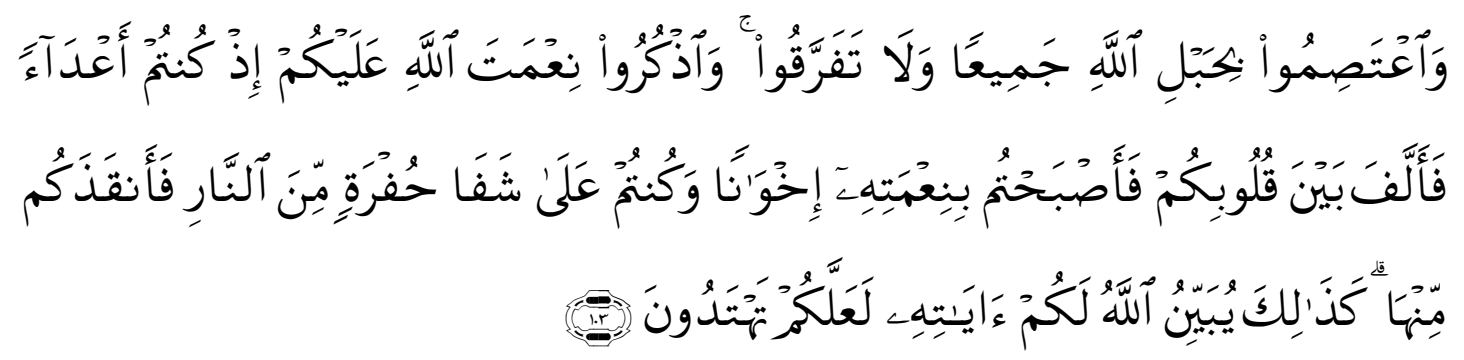

Dan berpeganglah kamu semuanya kepada tali (agama) Allah, dan janganlah kamu bercerai berai, dan ingatlah akan nikmat Allah kepadamu ketika kamu dahulu (masa Jahiliyah) bermusuh-musuhan, Maka Allah mempersatukan hatimu, lalu menjadilah kamu karena nikmat Allah, orang-orang yang bersaudara; dan kamu telah berada di tepi jurang neraka, lalu Allah menyelamatkan kamu dari padanya. Demikianlah Allah menerangkan ayat-ayat-Nya kepadamu, agar kamu mendapat petunjuk.

Gagasan mahabbah (rasa cinta) sebagai pengikat individu-individu sangat penting untuk membangun kekuatan kolektif atau jama'ah organisasi. Di atas gagasan mahabbah, persatuan dan kesatuan organisasi menjadi tegak dan kukuh. Di atas gagasan itu pula setiap individu berusaha untuk membahagiakan dirinya sendiri, saling tolong menolong dan mengikatkan serta menguatkan yang satu terhadap yang lain. Mengelola perubahan oleh kepala madrasah membutuhkan gagasan tersebut untuk membentuk ikatan persaudaraan yang kuat.

Semangat membangun kebersamaan bertumpu pada nilai spritual yang berkenaan dengan keterkaitan orang-orang sebagai kesatuan organis, yakni jika satu sakit akan berarti 
sakit secara keseluruhan. Al-Qur'an dan Hadis menyebutkan nilai spritual ini dengan berbagai ungkapan, diantaranya surat al-Ma'idah; 2 yang berbunyi:

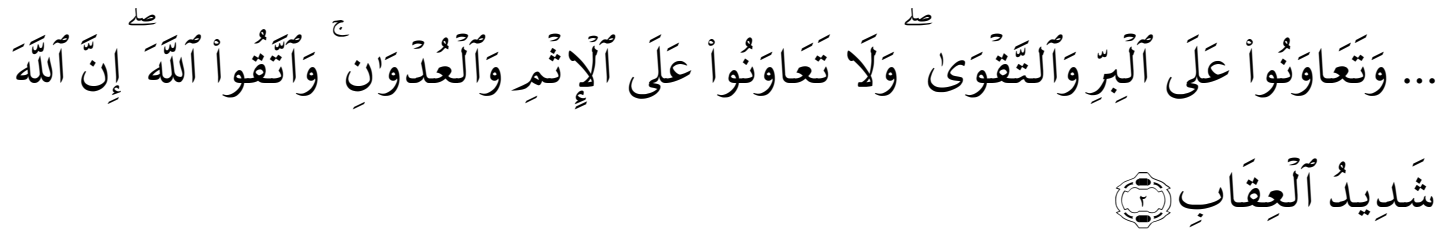

...Dan tolong-menolonglah kamu dalam (mengerjakan) kebajikan dan takwa, dan jangan tolong-menolong dalam berbuat dosa dan pelanggaran. dan bertakwalah kamu kepada Allah, Sesungguhnya Allah Amat berat siksa-Nya.

Dalam sebuah hadis terungkap, bahwa:

Seorang mukmin terhadap mukmin lainnya seumpama bangunan saling mengukuhkan satu dengan lain (kemudian Rasulullah saw merapatkan jari-jari tangan beliau).

Kekuatan disertakan pada Jama'ah. Barang siapa menyimpang (serong dan memisahkan diri), maka ia menyimpang menuju neraka.

Kesatuan yang tidak terpisah, rasa menyeluruh dan menyatu dengan yang lain, menjadi satu kekuatan utama yang kan menghasilkan tujuan-tujuan yang direncanakan (visi dan misi).

Kepala madrasah memang dapat membentuk rasa "kebersamaan" dan rasa memiliki terhadap madrasahnya, maupun keterlibatan dalam pencapaian tujuan. Kebersamaan ini hanya dapat dimunculkan jika kepala madrasah memiliki sikap dan melihat eksistensi sebagai pemimpin justru sebagai bagian dari kumpulan eksistensi setiap anggota madrasah, dan bukan sebaliknya. Kepala madrasah dapat memotivasi munculnya rasa percaya diri bawahanya melalui kapabilitas atau kompetensi yang dimiliki, dilengkapi dengan kerendahan hati untuk menyatakan bahwa proses yang sedang dilaksanakan merupakan "milik bersama". Konsekuensinya, para kepala madrasah harus dapat memposisikan dirinya sebagai "inisiator perubahan", "pelayan perubahan", dan secara aktif harus bisa menunjukkan partisipasi langsung dalam proses perubahan. Perilaku ideal kepala madrasah ini berdasar kepada sejauhmana pemimpin menunjukkan perilaku yang mendorong bawahanya agar mempunyai visi dan tujuan yang sama, untuk mendukung pemimpinya, dan membangun tingkat kepercayaan yang tinggi (Bass \& Avolio: 1996).

Kebersamaan harus dibangun dari perbedaan dan keragaman oleh kepala madrasah dalam mengembangkan dan menginovasi madrasah, bukan malah memunculkan pertengkaran dan pertikaian yang berujung pada kegagalan. Dengan kebersamaan segalanya akan menjadi mudah, apalagi proses perubahan membutuhkan kerjasama semua pihak. Akan terasa berat bilamana perubahan hanya dilakukan secara sendirian. Allah 
dalam firmannya surat al-Hujurat; 13 telah mengisyaratkan hal tersebut, bahwa Allah menantang pemimpin untuk menciptakan kebersamaan dalam perbedaan.

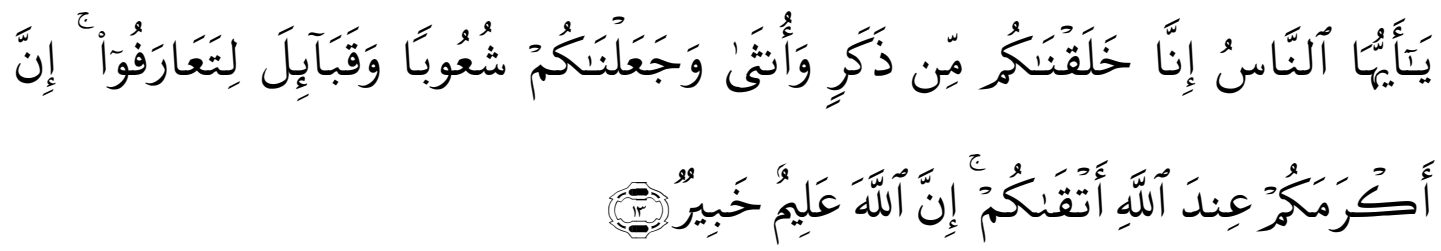

Hai manusia, Sesungguhnya Kami menciptakan kamu dari seorang laki-laki dan seorang perempuan dan menjadikan kamu berbangsa - bangsa dan bersuku-suku supaya kamu saling kenal-mengenal. Sesungguhnya orang yang paling mulia diantara kamu disisi Allah ialah orang yang paling taqwa diantara kamu. Sesungguhnya Allah Maha mengetahui lagi Maha Mengenal.

Ayat ini mengisyaratkan bahwa seorang kepala madrasah harus memahami sosiologis dan antropologis bawahannya, sehingga ia dapat memahami watak dan karakter komunitas madrasah yang dipimpinnya. Tugas dari kepala madrasah adalah memenej perbedaan dan keragaman anggota madrasah sebagai aset dan kekuatan madrasah. Tugas kepala madrasah bukanlah memaksakan persamaan, namun, untuk mengelola perbedaan dan keragaman. Perbedaan ras, suku, bangsa, agama dan apapun di kalangan bawahanya, seharusnya menjadi ajang kompetisi untuk menjadi yang terbaik dan lebih baik serta lebih dekat di sisi Allah swt. Orang yang paling berperan dalam penciptaan kondisi yang kondusif tersebut adalah kepala madrasah.

Berdasarkan studi-studi Ohio tentang ciri sekolah sukses, digambarkan bahwa kepala madrasah menaruh perhatian pada perasaan-perasaan bawahannya dan menghargai gagasan-gagasan mereka (perilaku konsiderasi) (Gregory Moorhead \& Ricky W. Griffin, : 1998). Menghargai orang lain dimaknai sebagai mengakui dan menghormati keberadaan, pendapat dan eksistensi orang lain. Sebenarnya kutipan yang terdapat pada nilai persamaan -sebagaimana yang telah dibahas sebelumnya- juga telah menunjukkan adanya penghargaan kepala madrasah kepada anggota madrasah yang lain. Dengan mengajak bawahan untuk bekerjasama, mengakui keberadaan orang lain, mengakui ide dan gagasan bahkan mengikuti saran dan nasehat orang lain adalah juga bentuk apresiasi terhadap orang lain. Kepala madrasah seringkali melihat latarbelakang orang yang lain ketika ingin memberikan penghargaan dan pengakuan dalam bentuk promosi jabatan. Hal ini sejalan dengan semangat al-Qur'an surat al-Hujurat: 13 sebagaimana tersebut di atas.

Temuan pada penelitian ini juga menggambarkan bahwa kepala madrasah memiliki nilai empati dan peduli yang tinggi terhadap orang lain. Kasus Penelitian ini menggambarkan bahwa kepala madrasah berusaha memahami kebutuhan peserta didik, seperti kebutuhan jenis toilet untuk peserta didik. Memahami latar belakang anak didik 
yang berbeda-beda, kepala madrasah menyediakan toilet yang duduk maupun yang jongkok sesuai kebutuhan anak didiknya. Kepala madrasah selalu memberikan penghargaan baik terhadap guru maupun siswa yang berhasil dalam kegiatan tertentu, misalnya berhasil menjuarai lomba atau pertandingan tertentu.

Kepala madrasah juga sangat apresiatif terhadap kondisi seseorang, oleh karenanya beliau sangat empati dan peduli dengan kondisi bawahan. Apa yang dilakukan kepala madrasah adalah dalam rangka untuk menekan kesenjangan sosial yang dapat menimbulkan rasa iri dan dengki. Ayat al-Qur'an surat al-Hajj; 41 jelas menganjurkan akan hal tersebut sebagaimana ayat berikut.

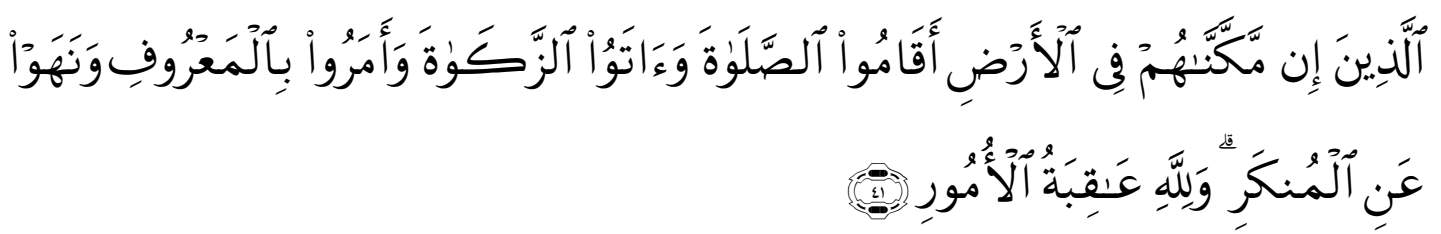

(yaitu) orang-orang yang jika Kami teguhkan kedudukan mereka di muka bumi niscaya mereka mendirikan sembahyang, menunaikan zakat, menyuruh berbuat ma'ruf dan mencegah dari perbuatan yang mungkar; dan kepada Allah-lah kembali segala urusan.

Dengan demikian, dari pembahasan dan uraian di atas terkait dengan nilai-nilai dan keyakinan yang melandasi praktik kepemimpinan kepala madrasah, dapat dirumuskan bahwa praktik-praktik kepemimpinan kepala madrasah dalam mengelola Madrasah Ibtidaiyah sukses dilandasi oleh nilai-nilai dan keyakinan personal (moralis), profesional dan kemanusiaan. Ini berarti bahwa kepemimpinan madrasah sukses tidak hanya persoalan niat baik (nilai dan kepercayaan), tetapi juga tindakan. Oleh karena itu, esensi kepemimpinan sebenarnya, di atas segalanya adalah tindakan (Ingram T. Keith: 1997). Hal tersebut telah melahirkan kepemimpinan yang menginspirasi komunitas madrasah dengan nilai dan keyakinan yang dipercayainya, yang disebut dengan moralis transformasional.

Kepala madrasah menjalankan karakteristik kepemimpinan tertentu yang memberikan kontribusi terhadap pencapaian outcome siswa yang berhasil. Karena itu, dari studi ini muncul apa yang disebut para peneliti sebagai sebuah model kontemporer untuk kepemimpinan edukasional (contemporary model of educational leadership) dan telah memberikan suatu inspirasi untuk pengembangan model tersebut (King dan Newman: 2001). 


\section{SIMPULAN}

Berdasarkan uraian hasil penelitian di atas, dapat disimpulkan sebagai berikut:

1. Keberhasilan sebuah madrasah mencerminkan nilai-nilai dan keyakinan spritual yang dimiliki kepala madrasah mengenai apa yang harus dicapai oleh sekolah. Nilai dan keyakinan spritual sangat berpengaruh terhadap praktik kepemimpinan kepala madrasah dalam mengembangkan dan mengubah madrasah menjadi lebih baik, mulai dari proses-proses dan prosedur-prosedur kepemimpinannya. Hal ini sejalan dengan prinsip-prinsip kepemimpinan moralis, bahwa nilai spritual merupakan hal pokok bagi praktik-praktik kepemimpinan dan administrasi. Selain nilai moral ini, kepala madrasah dengan segenap komitmen personalnya, wali murid, guru, staf non guru untuk melakukan tindakan yang benar bagi siswa. Ini berarti bahwa kepemimpinan madrasah sukses tidak hanya persoalan niat baik (nilai dan kepercayaan), tetapi juga tindakan. Oleh karena itu, esensi kepemimpinan sebenarnya, di atas segalanya adalah tindakan.

2. Oleh karena itu, kepemimpinan moralis transformasional memiliki lima tuntutan kepemimpinan: sumber daya manusia, tututan teknis, simbolik, kultural dan edukasional. Tuntutan teknis kepemimpinan mencakup teknik-teknik mengelola yang baik sebagai syarat bagi setiap organisasi; tuntutan sumber daya manusia mencakup pemanfaatan potensi-potensi sosial dan inter personal dari sdm sekolah; tuntutan edukasional menunjukkan pengetahuan tentang pendidikan dan persekolahan yang baik; tuntutan simbolik menekankan contoh pada tujuan dan sikap; sedang kepemimpinan kultural menekankan pada nilai-nilai hidup, kepercayaan, dan kultur dan hal tersebut memberikan identitas tersendiri bagi sekolah dari waktu ke waktu. Peran kepemimpinan ini dapat mengubah dan mentransformasi madrasah menjadi komunitas dan menginspirasikan beragam komitmen yang tinggi, kekuasaan, dan pelayanan prima yang menjadikan sekolah tidak dapat disamakan dengan institusi masyarakat lainnya. 


\section{DAFTAR PUSTAKA}

Al-Munawar, S.A.H. (2002). Al-Qur'an Membangun Tradisi Kesalehan Hakiki (Jakarta: Ciputat Press.

Al-Qur'an dan Terjemahannya ke Dalam Bahasa Indonesia (dicetak dengan biaya pribadi di Pangeran al-Walid bin Thalal bin Abdul Aziz Ali Sa’ud), Riyadh-Saudi Arabia.

Arifin, I. (1999). Strategi Pengelolaan MI Unggulan; Analisis Evaluatif dalam Menyusun Perencanaan Strategik MI Unggulan. Ilmu Pendidikan; Jurnal Filsafat, Teori dan Praktik Pendidikan, 26(1)

Bass, B.M. \& Avolio, B.J. (1996). Multifactor Leaderhip Questionnaire Report. California: Mind Gardens.

Bogdan, R. \& Biklen, S.K. (2003). Qualitative Research for Education: An introduction to Theories and. Methods (4th ed.) New York: Pearson Education group.

Boko, H., Wolf, S.A., Simone, G. \& Uchiyama, K.P. 2003. Schools in transition: Reform efforts and school capacity in Washington state. Educational Evaluation and Policy Analysis, 25(2).

CD Mausu'ah al-Hadis al-Syarif, dengan kata kunci salaka, Hadis ini diriwayatkan oleh Imam al-Tirmidzi dalam kitab Sunannya, pada bab al-Ilmu `an rasulillah, sub bab fadlu talabil ilmi.

Djalil. A. Sekolah Alam Bilingual TK-SDI-MTs-PONTREN Surya Buana Jl Gajayana IV/631 Malang.

Dubin, A.E. (1991). The Principal as Chief Executive Officer. London: The Falmer Press

Duignan, Patrick A, Bhindi, Narottam \& Pherson, M. (1993). Educative Leadership: A Practical Theory. Eductional Administration Quarerly. 29 (1).

EMIS; 2017. Education Management Information System, TU Binbaga Depag.

Fadjar, A. M. (1996). Sekolah Islam Harus Berkualitas. Amanah. Mei. 1996.6 (10)

Frymier. J.R., dkk. (1984). One Hundred Good School. Indiana: Phi Delta Kappa Publication.

Fullan, M. (1998). Change Force: Probing the Depths of Educational Reform London: Falmer Press.

Furchan, A. (1995). “Manajemen Pemasaran Madrasah: Antisipasi Masa Depan”. Makalah Seminar Nasional. Malang: Unisma Malang

Gill, R. (2003). Change Management or Change Leadership. Journal of Change Management 3(4).

Glickman, C.D., Gordon, S.P. \& Ross-Gordon. (2001). Supervision and Instructional Leadership: A Developmental Approach. Boston: Alyn \& Bacon.

David, G.D., Drysdale. Lawrie, Mulford. Bill, (2005). Succesful Principal Leadership: Australian Case Studies. Journal of Educational Administration. 43

Harris, C. D. (2005). Sustaining Succes in Challenging Context: Leadership in English School. Journal of Educational Administration. 43.

Henderson. E.S. and Perry, G.W. (1997). Change and Development in School: Case Studies in The Management of School-Focused in Service Education. London: McGraw-Hill Book Company (UK) Limited 
Hill, P.W. "What All Principals Should Know About Teaching and Learning. San Fransisco: Jossey Bass.

Hosking, D.M. (1998). Organizing, Leadership and Skilfull Process. Journal of Management Studies, 25(2).

Ingram, T. K. (1997). Leadership Behaviours of Principalsn Inclusive Eduvational Settings. Journal of Educational Administration, 35(5).

King, M. B \& Frank, M. N. Building School Capacity through Professional Development: Conceptual and Empirical Considerations. The International Journal of Educational Management, 20(1).

Kompas.com, 04/10/2012.

Kowalski, J. \& Oates, W. (1993). The Evolving Role of Superinterdents in School-Based Management. Journal of School Leadership, 5(4).

Leithwood, A. K. \& Jantzi, D. (1997). Explaining Variation in Teachers' Perceptions of Principals; Leadership: A Recliation. Journal of Educational Administration, 35(4).

Leithwood, A. K.\& Jantzi, D. (2000). The Effect of Transformational leadership on Organizational Conditions and Student Engagement with School. Journal of Educational Administration, 38(2).

Leithwood, A. K. \& Jantzi, D. (2003). Transformational Leadership Effects on Teachers' Commitment and Effort toward School Refrom. Journal of Educational Administration, 41(3).

Leithwood, A. K. (2005). Understanding Successful School Leadership: Progress on a Broken Front. Jounal of Educational Administration, 43(6).

Leithwood, K.A. \& Daniel, L. D. (1999). A Century's Quest to Understand School Leadership. J. Murphy \&Karen Seashore Louis (eds), Handbook of Research on Educational Administratio. San Fransisco: Jossey-Bass Publisher.

Leithwood, K.A. and Riehl, C., "What Do We Already Know About Succesfull School Leadership?" diperoleh pada tanggal 26 Februari 2017, melalui http://www.cepa.gse.rutgers.edu.

Leithwood, K.A., Louis, K.S., Anderson, S. and Wahlstrom, K."How Leadership Influences Student Learning", didapat pada tanggal 26 Februari 2017, melalui http://www.wallacefoundation.org

Lincoln, S. Y.\& Guba, G. E. (1985). Naturalistic Inquiry. California: Sage Publication. Inc

Miles, B. M. \& Huberman, A. M. (1984). Qualitative Data Analysis. California: Sage Publication. Inc.

Moorhead, G. \& Griffin, R.W. (1998). Organizational Behaviour: Managing People and Organization ( $5^{\text {th }}$ ed). Boston: Houghton Mifflin Company.

Raharjo, M. D. (2002). Ensiklopedi Al-Qur'an: Tafsir Sosial Berdasarkan Konsep-Konsep Kunci. Jakarta: Paramadina.

Sergiovanni, J. T. (1987). The Principalship: A Reflective Practice Perspective Boston: Allyn and Bacon, Inc.

Sergiovanni, J. T. (1992). Moral Leadership: Getting the Heart of Shool Improvement. San Fransisco: Jossey-Bass Publishers.

Shochib, M. (2006). Peranan Keluarga dalam Menanamkan Disiplin-Diri bagi Anak: Suatu Tela'ah Reflektif Teoritis. Jurnal Ilmu Pendidikan. Januari, 23(1): 45-55. 
Muhammad Walid, Nilai dan Keyakinan, Kreatifitas dan Kepemipinan Kepala Madrasah...

Steenbrink, K.A. (1996). Pesantren, Madrasah, Sekolah; Pendidikan Islam dalam Kurun Modern. Jakarta: PT. LP3ES.

Yin, R.K. (1994). Case Study Research: Design \& Methode. California: Sage Publication. Inc. 